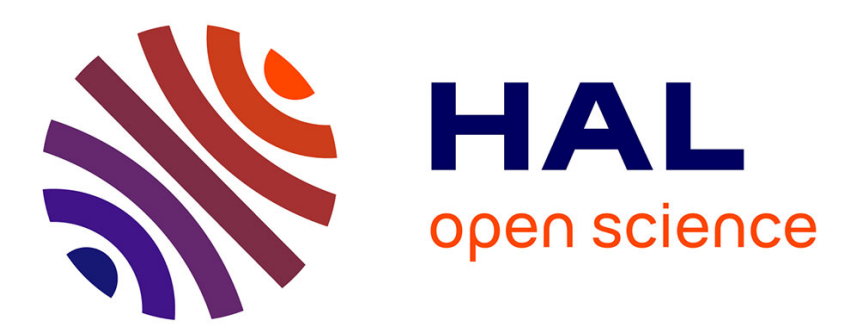

\title{
Mechanical Spectroscopy and Structural Evolution of Thin CuMo Films
}

\author{
V. Branger, V. Pelosin
}

\section{To cite this version:}

V. Branger, V. Pelosin. Mechanical Spectroscopy and Structural Evolution of Thin CuMo Films. Journal de Physique IV Proceedings, 1996, 06 (C8), pp.C8-807-C8-810. 10.1051/jp4:19968173 . jpa00254609

\section{HAL Id: jpa-00254609 https://hal.science/jpa-00254609}

Submitted on 1 Jan 1996

HAL is a multi-disciplinary open access archive for the deposit and dissemination of scientific research documents, whether they are published or not. The documents may come from teaching and research institutions in France or abroad, or from public or private research centers.
L'archive ouverte pluridisciplinaire HAL, est destinée au dépôt et à la diffusion de documents scientifiques de niveau recherche, publiés ou non, émanant des établissements d'enseignement et de recherche français ou étrangers, des laboratoires publics ou privés. 


\title{
Mechanical Spectroscopy and Structural Evolution of Thin CuMo Films
}

\author{
V. Branger and V. Pelosin* \\ Laboratoire de Métallurgie Physique, URA 131 du CNRS, Faculté des Sciences de Poitiers, BP. 179, \\ 89960 Futuroscope cedex, France \\ * Laboratoire de Mécanique et de Physique des Matériaux, URA 863 du CNRS, ENSMA, Site du \\ Futuroscope, BP. 109, 89960 Futuroscope cedex, France
}

\begin{abstract}
It is well known that in thin metallic films, the anelastic and the elastic properties show some characteristic features linked to the specific microstructure. The studied films $\mathrm{Cu}_{30} \mathrm{Mo}_{70}$, with a typical thickness of $200 \mathrm{~nm}$ are deposited by Ion Beam Sputtering (IBS) on oxidised silicon (100) substrates. The measurements are performed on a vibrating reed device adapted for thin adherent films over a temperature range between $20^{\circ} \mathrm{C}$ and $450^{\circ} \mathrm{C}$.

This paper reports the combined results of internal friction, elastic modulus and internal stresses measured during thermal cycling. "Direct" observations of the microstructure are performed by X-Ray diffraction. We have correlated the modifications of the mechanical properties with the structural evolution of these metastable systems.
\end{abstract}

\section{INTRODUCTION}

The new deposition techniques, developed in the last decade, allow to obtain classes of materials, which could not be produced by classical elaboration. Then, a sursatured "solid solution" of Cu-Mo could be realised by Ion Beam Sputtering (IBS), though the positive heat of mixing $(\Delta \mathrm{H})$. Recently, it was reported that this binary system, for a $\mathrm{Cu}$ content of 30 at $\%$, presents a very important resistance to the abrasion and permits a good adhesion between $\mathrm{Mo}$ and $\mathrm{CuInSe} \mathrm{I}_{2}$ in the solar cells applications [1]. Studies about the thermal stability of this "alloy" have shown distinct features of microstructural changes [2]. First, a stress relaxation occurs in the film in a temperature range between $20^{\circ} \mathrm{C}-300^{\circ} \mathrm{C}$, then, an anisotropic growth of the nanocrystallites appears between $300^{\circ} \mathrm{C}$ and $500^{\circ} \mathrm{C}$. At least, for annealing up to $500^{\circ} \mathrm{C}$, the metastable solid solution collapses and $\mathrm{Cu}$ precipitates at the Mo grain boundaries.

Our purpose is to combine the results obtained by the $\mathrm{X}$ ray diffraction (XRD) analysis and the measurements of internal friction on such deposits. Indeed, internal friction is very sensitive to small changes in the mechanical and microstructural states of a material and thus important information could be obtained about the effect of the thermal treatments before the whole crystallisation. We will also follow up the elasticity properties and the resistivity of the film during annealing.

\section{EXPERIMENTAL DETAILS}

Mo-Cu thin films were produced using an Ion Beam Sputtering (IBS) system with a split-target arrangement [2]. The films were deposited onto oxidised $\mathrm{Si}(100)$, quartz and specially shaped reeds of the same materials for the elastic and the anelastic measurements. The deposition rate was about $0.2 \mathrm{~nm} / \mathrm{s}$ and the thickness of the films was $200 \mathrm{~nm} \pm 5 \mathrm{~nm}$. The vacuum before depositing films was under $10^{-7}$ Torr. The measurements of the $\mathrm{Cu}$ concentration in the films was achieved by Energy Dispersive Spectrometry (EDS) and was found to be around $30 \%+2 \%$ for specimens reported in this paper. The in situ measurements of the reed deflexion allow us to follow the internal stresses in the film during annealing using the "curvature" method [3]. 
Internal friction and elasticity measurements were performed using a vibrating reed device, specially adapted to the study of thin metallic films. The experimental set up has been described elsewhere [4]. The damping was determined from the free decays of the reed vibration. The samples were characterised by $X$ ray diffraction $(\mathrm{XRD})$ using a copper $\mathrm{K} \alpha_{1}$ radiation produced by a Rigaku generator. The diffractometer was enclosed under a vacuum of $10^{-2}$ Torr in order to minimize the background level. The position of the diffraction peaks was determined in a $\theta / 2 \theta$ geometry. Silicon powder pasted on a $\mathrm{Si}(100)$ substrate was used as standard. The electrical resistivity of the films was determined by a classical four-point probe method. For the X-ray diffraction and the resistivity analysis, the film were annealed in a chamber under $10^{-6}$ Torr at different temperatures $\left(200^{\circ} \mathrm{C}, 300^{\circ} \mathrm{C}, 400^{\circ} \mathrm{C}, 500^{\circ} \mathrm{C}\right.$ and $\left.700^{\circ} \mathrm{C}\right)$ for a period of 60 minutes.

\section{RESULTS AND DISCUSSION}

X-ray diffraction analysis (figure 1) shows that the microstructure of the as deposited films consists on a metastable solid solution of $\mathrm{Cu}$ in Mo. This result has been confirmed by EXAF's measurements on the same samples. This microstructure is very far away from the thermodynamically equilibrium and doesn't seem to change before an annealing of $300^{\circ} \mathrm{C}$. Until this temperature, nevertheless, we could see the shift of the X-ray diffraction peak to the high values of $2 \theta$ angles, which reflects the generation of tensile stresses in the film or/and the diminution of the unit cell volume. Between $300^{\circ} \mathrm{C}$ and $400^{\circ} \mathrm{C}$, the intensity of the Mo (110) peak increases. Appearance of the very weak (111) Cu peak, leads to the assumption that the phase separation phenomenon occurs. For annealing temperature up to $400^{\circ} \mathrm{C}$, the intensity of the (111) $\mathrm{Cu}$ and (110) Mo peaks increases, which accounts for the growth of the crystallites. From these results, we may conclude that the demixion processes begins only for an annealing temperature higher than $300^{\circ} \mathrm{C}$.

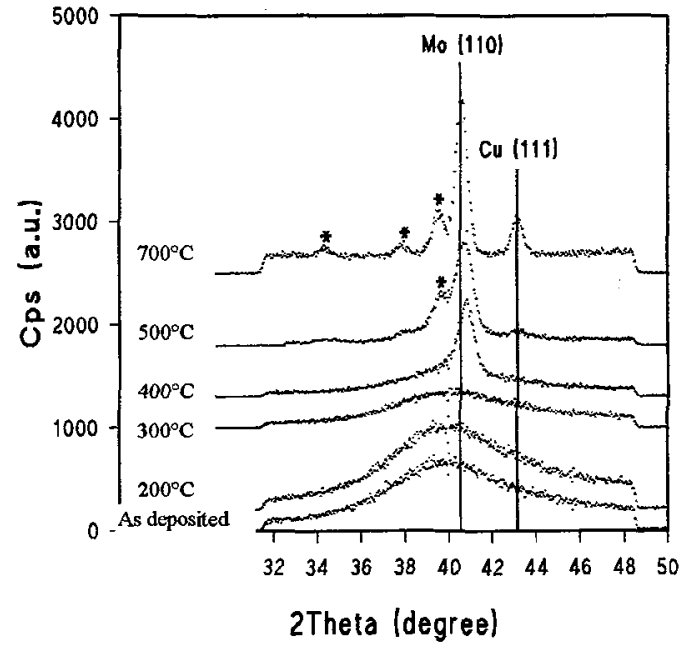

figure 1: X-Ray diffraction measurements on $\mathrm{Cu} 30$ Mo70 samples, after different annealings $(\theta / 2 \theta$ geometry). The peaks marked * could not be indexed unambiguously and have been observed before by Ramanath [2].

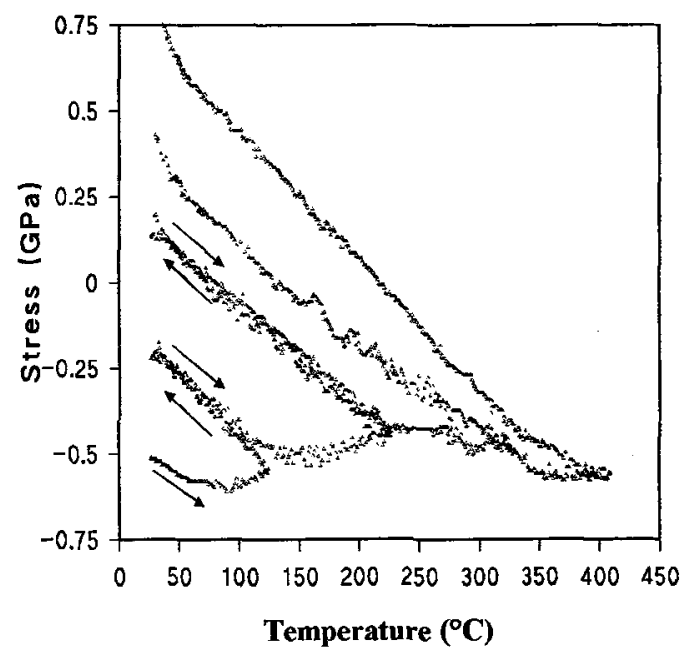

figure 2: In situ measurements of stress on Cu30 Mo70 specimen during thermal cycling.

The in situ measurement of stresses (figure 2) reveals that the as deposited films are in a compression state $(-0.5 \mathrm{GPa})$. This state of stress is usually characteristic of the disordered sputtered microstructures, more exactly in our case, it could reveals the presence of interstitial atoms in the unit cell or substitutional atoms 
with an important atomic volume (> vol. at. of Mo) [5]. On heating above $90^{\circ} \mathrm{C}$, the compressive stresses, generated by the differential thermal expantion between the metallic film and the Si substrate, become large enough to cause plastic flow in the film. Then, the stress curve tends to flatten. This phenomenon appears on each subsequent heating with an elastic zone covering wider temperature range. One may notice that the major evolution of stress magnitude occurs for annealing temperature range between $120^{\circ} \mathrm{C}$ and $220^{\circ} \mathrm{C}$. During different thermal cyclings, tensile stresses are generated in the film and reach a value of $0.75 \mathrm{GPa}$ after a $430^{\circ} \mathrm{C}$ annealing. This result could be explained by a structural relaxation as observed in the metallic glasses before the crystallisation [6]. Indeed, this phenomenon involves a short range order, then a decrease of the film volume. For annealing up to $430^{\circ} \mathrm{C}$, the stress state in the film doesn't vary significantly. From the slope of the curves (in the elastic deformation regions) and by applying the method explain by Thouless [7], we may determined the biaxial modulus (E/(1-v)) (for $\mathrm{T}<100^{\circ} \mathrm{C}$ ). The value of modulus thus determined was respectively estimated as $340 \mathrm{GPa}$ for the as deposited films and $410 \mathrm{GPa}$ after a $500^{\circ} \mathrm{C}$ annealing. This corresponds to a $20 \%$ increases upon demixion. In spite of an experimental uncertainty of a few percents, the hardening with annealings may originate in a combination of several factors: very poor crystallisation of the as deposited film, elimination of numerous defects in the Mo unit cell with annealings... . The " theorical " value, determined by weighting the biaxial modulus of respective pure elements by their \% volume in the film was about 380GPa. The difference between the value of $500^{\circ} \mathrm{C}$ annealing film and the "theorical" one is not yet clearly explained but could be the result of the approximation in the calculation.

In figure 3, we have reported the normalized flexural modulus (determined by the resonant frequency of the reed: silicon and film) versus annealing temperatures. According to the fact that the silicon modulus is not supposed to be changed by the thermal treatments, we have ascribed the modulus variations to the film only. Then, in the $20-320^{\circ} \mathrm{C}$ temperature range, the $\mathrm{M} / \mathrm{Mo}$ variation correspond to a $10 \%$ increase of the film flexural modulus [3]. A further increase of $14 \%$ is observed after a $550^{\circ} \mathrm{C}$ annealing. This two different stages in the modulus modification may be related with those observed in the metallic glasses. Indeed, in this case, before the crystallisation, which can product until a $30 \%$ increasing of the modulus [8], a structural relaxation (chemical local relaxation), characterised by a $10 \%$ increasing on the modulus, takes place with an important stress relaxation. This phenomenon corresponds to the evolution of an amorphous state to an other one (more stable).

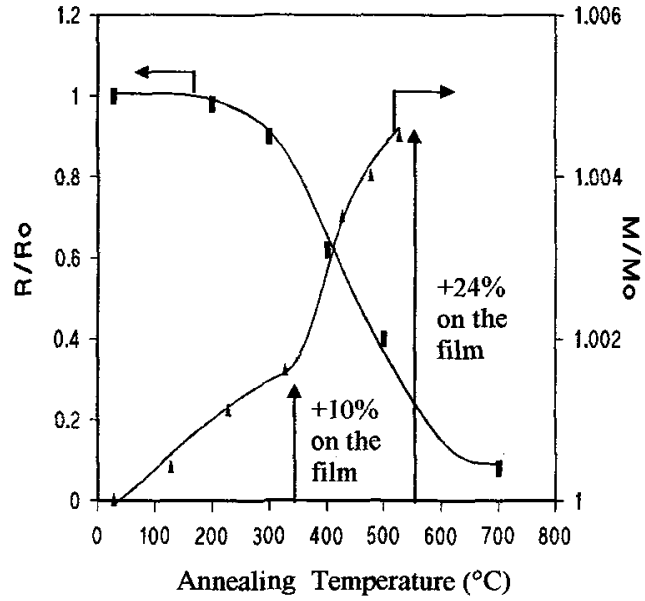

figure 3: Normalised resistivity (1) and flexural modulus (A) measured at room temperature $\left(25^{\circ} \mathrm{C}\right)$ after different annealings

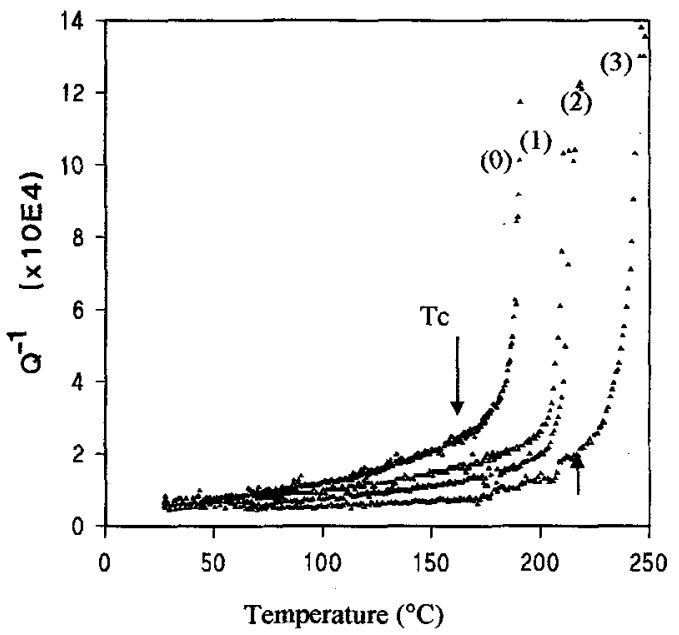

figure 4: Internal friction v.s. temperature curves for a Cu30 Mo70 specimen : (0) as deposited, (1) after the first $400^{\circ} \mathrm{C}$ annealing, (2) after the second $400^{\circ} \mathrm{C}$ annealing and (3) after the third one. 
Figure 3 also shows the resistivity evolution normalised to that at $20^{\circ} \mathrm{C}$ versus annealing temperature. The curves were obtained for the $\mathrm{Cu} 30-\mathrm{Mo} 70$ films deposited on quartz. For an annealing temperature lower than $200^{\circ} \mathrm{C}$, the resistivity doesn't seems to evolve. Between $200^{\circ} \mathrm{C}$ and $300^{\circ} \mathrm{C}$ a small decrease of the resistivity may be caused by an atoms transfer within an atomic arrangement across distances of one lattice spacing (short range order). For annealings up to $300^{\circ} \mathrm{C}$, the resistivity is diminushed by a factor of five. This behaviour is a typical reflection of a ordering phenomenon [8]. This last result is in perfect agreement with the demixion phenomenon.

Internal friction has also been measured after thermal annealing. Figure 4 depicted the evolution of damping determined on heating only after different treatments : (0) as prepared state, (1) first anneal at $400^{\circ} \mathrm{C},(2)$ second anneal at $400^{\circ} \mathrm{C},(3)$ third anneal at $400^{\circ} \mathrm{C}$. It is clear that $\mathrm{Q}^{-1}$ decreases with the number of annealings. This effect could be attributed to the structural ordering. In addition, for each measurements, the damping increases exponentially from a critical temperature (noted Tc on the figure which is shifted to the high temperatures. Such a behaviour is typical of a structural relaxation. This phenomenon occurs considerably below the demixion temperature and shows that microstructural change takes place at relatively low temperature.

\section{CONCLUSION}

The presence of a structural relaxation, usually observed before the crystallisation in metallic glasses, has been shown for the $\mathrm{Cu}_{30} \mathrm{Mo}_{70}$ thin films deposited by sputtering. This structural relaxation is characterised by a decrease of the resistivity, a 10\% modulus increasing and an exponentially increase of the damping. In our case, the structural relaxation takes place in a temperature range between $200^{\circ} \mathrm{C}$ and $300^{\circ} \mathrm{C}$ and involves a short range order. The demixion phenomenon observed by the $\mathrm{X}$-Ray diffraction analysis occurs between $300^{\circ} \mathrm{C}$ and $400^{\circ} \mathrm{C}$. This structural evolution has a greater magnitude: a additional $14 \%$ increase on modulus, drastic falling of the resistivity (the initial value is divised by 5) and involves an atomic arrangement across a long distance.

\section{ACKNOWLEDGMENTS}

The help of $O$. Proux during the preparation of the sample and EXAF's experiments is gratefully acknowledged. This work was in part supported by the "Conseil regional du Poitou-Charentes " (France)

\section{REFERENCES}

[1] S.M. Shin, M.A. Ray, J.M. Rigsbee, and J.E. Greene, Appl. Phys. Lett., 43, 249 (1983).

[2] G. Ramanath, H. Z. Xiao, L.C. Yang, A. Rockett, and L.H. Allen, J. Appl. Phys., 78 (4), 2435-2440 (1995).

[3] B.S. Berry and W.C. Prichet, J. Appl. Phys., 67 (8), 3661-3668 (1995).

[4] V. Pelosin, PhD thesis. University of Grenoble (France) (sept 93)

[5] Ph. Goudeau, J. Mimault, Th. Girardeau, K. Reklaoui, O. Proux, V. Branger, to be published in thin solid films, (1996).

[6] S. Tyagi and A.E. Lord Jr, Journ. of non Crystalline Sol. 30 273-283 (1979).

[7] M.D. Thouless, Annu. Rev. Mater. Sci. 25 69-96 (1995).

[8] A. Chamberod, P. Mangin, L'ordre et le désordre dans les matériaux, Les Ed. de Phys. 201-242 (1984). 